\title{
Community-Based Tourism and Destination Attractiveness: From Theory to Practice
}

\author{
Quynh Nga T. Vo \\ University of Economics, The University of Danang \\ 71 Ngu Hanh Son Street, Ngu Hanh Son District, Danang city, Vietnam \\ Orcid ID: https://orcid.org/0000-0001-6564-1149
}

\begin{abstract}
Community-based tourism (CBT) is an approach for tourism development that highlights the active participation of the community as a producer, owner, decision-maker in the tourism development of a destination. It has been considered as a sustainable tourism development orientation because it creates employment and increases income for local communities, making them more aware of the responsibility to preserve and enrich their local tourism resources. However, one of the crucial indicators of the sustainability of a CBT venture is commercial viability which is mostly influenced by destination attractiveness to the tourists. Firstly, this paper aims at identifying core attractive attributes from which CBT is frequently developed. A case-based study is carried out on thirty documented successful CBT practices in many parts of the world. From that, this paper points out five types of core attractive attribute of the destination on which CBT can be developed. Then, this paper will discuss how CBT can make a destination more attractive. Finally, the paper will suggest some actions for tourism policymakers of a CBT destination.
\end{abstract}

Keywords: community-based tourism, destination attractiveness, sustainable tourism, core attractive attributes, community participation

DOI: $10.7176 / \mathrm{JTHS} / 49-04$

Publication date:May $31^{\text {st }} 2020$

\section{Introduction}

Sustainable development in recent years has become an important consideration of strategic decisions, both at the national and international level. Consequently, sustainable tourism is increasingly being taken into account by policymakers. In a report on the contribution of tourism to poverty alleviation in 2002, WTO reviewed arguments and evidence for the significant role of sustainable tourism in improving the well-being of the local community and protecting simultaneously their environment. Thus, sustainable tourism development becomes a long-term strategic consideration of many developing countries as well as the least developed countries. In that development orientation, sustainability authentically results from the participation of the local community in planning and implementing tourism development (Dangi \& Jamal, 2016).

$\mathrm{CBT}$ is referred to as a pattern of tourism activities in which the community plays the role of a key stakeholder. They are involved in supplying the tourism product (Lucchetti \& Font, 2013), empowered to manage tourism growth (ASEAN, 2016). CBT is an approach of tourism development in which the community actively participates as a host of tourism products in addition to being a beneficiary. This has been considered as an orientation for sustainable tourism development as its benefits cover both economic, socio-cultural and environmental aspects. Economically, CBT creates greater job opportunities and increases local income, improves infrastructure and promotes linkage between sectors in the destination. Socio-culturally, CBT empowers the indigenous community in its development, preserves the cultural identity, improves the quality of life at the destination. And environmentally, CBT contributes to raising community's awareness of conservation, using sustainably the local natural resources (Tasci et al., 2013). However, for achieving these benefits, sustainable CBT is supposed to be commercially viable (Luchetti \& Font, 2013). In other words, CBT is assumed to promote tourists traveling to a destination.

In recent years, the world has witnessed the continuous expansion of the tourism market However, there is a simultaneously increasing competition between destinations as many mature destinations are jostled by emerging destinations to get tourist's visitation. Therefore, destinations need to continuously seek or create sources of competitive attractiveness to win the tourists' choices (Krešić \& Prebežac, 2011). Destination choice is a key decision in the travel-decision making process (Wu, 2012). According to $\mathrm{Wu}$ (2012), destination attractiveness is an essential alternative-specific factor influencing destination choice decision. Destination attractiveness is an umbrella notion of destination attributes that attract or motivate tourists to travel to a particular destination (Krešić $\&$ Prebežac, 2011). These attributes may be natural or man-made. But whatever they are, they are supposed to be attributes of the destination that visitors perceive appealing to them, and embody the destination's ability to satisfy their needs (Formica \& Uysal, 2006). CBT is a type of tourism developed through the promotion of tourist products characterized by community participation as co-producer (López-Guzmán et al., 2011). With that characteristic, double questions are forwarded: i) which core attractive attribute of a particular destination that CBT development 
can be based on, and ii) how CBT, its turn, can make the destination more attractive to accomplish its commercial viability.

Based on analysing thirty successful CBT practices in many parts of the world, this paper aims at identifying core attractive attributes from which CBT can be developed. Then, this paper will discuss how CBT can make a destination more attractive. Finally, the paper will suggest some actions for tourism policymakers of a CBT destination.

\section{Literature review}

\subsection{Destination attractiveness and core attractive attributes}

Tourism destination is defined as many ways. Estevão, Garcia \& De Brito Filipe (2015) describe destination as a physical space that visitors can travel to and experience at least one night. This space has tourism products which include attractions, tourism resources and supporting infrastructure. A tourism destination is sometimes referred to as a fundamental tourism product (Ritchies \& Crouch, 2003) and usually conceptualised as local entities that can include cities, towns, or regional areas (Lew \& McKercher, 2006). Tourism destinations compete with each other for tourists' choice which is influenced by the attractiveness of the destinations (Formica \& Uysal, 2006).

Destination attractiveness may be taken meaning from the demand approach and supply approach (Formica \& Uysal, 2006). From demand approach, attractiveness is defined as "reflection of the feelings, beliefs and opinions" that a potential tourist has about the perceived ability of a destination to satisfy his/her needs during the vacation (Hu \& Ritchie,1993). According to the supply approach, attractiveness represents for destination's forces which pull visitors to the destination (Formica \& Uysal,2006). From an integrated approach, attractiveness is a bundle of destination attributes that appeal visitors to travel to the destination. In short-term, destination attractiveness influences visitors' decision to choose the destination among the competing destinations. In longterm, destination attractiveness affects visitor's loyalty toward a destination (Vigolo, 2015).

The attractiveness of a destination is believed to manifest in many ways. Many scholars suggested different measurements for a destination's attractiveness (Vegesayi, Mavondo \& Reisinger, 2009). Even though the measurement scales are not identical but they share the same idea that the attractiveness of a destination can be predicted by many attributes to appeal tourists to the destination. According to Ariya, Whishitemi and Sitati (2017), these attributes can belong to many different groups depending on study approach and study context which may include categorizing of $\mathrm{Hu}$ and Ritchie (1993), Buhalis (2000), Goeldner, Ritchie and McIntosh (2000), Kim et al. (2003), Formica and Uysal (2006) etc. In general, these attributes may be "given", for example, beautiful beaches, comfortable climate, impressive mountains, amazing historical-natural buildings... or "man-made" like package tours, hotels, transportation, and entertainment facilities... (Van Raaij, 1986). Based on the integration of previous studies, Vegesayi et al. (2009) categorised these attributes into three groups: attractions, support services, and people-related factors. Attraction factors include natural and man-made resources that offer tourists reasons to visit a destination (Lew \& McKercher, 2006) such as a pyramid, a museum, an imposing landscape... Attractions are regarded as a "physical manifestation" of the attractiveness of a destination (Krešić \&Prebežac, 2011) and the main component of a destination's attractiveness (Ritchies \& Crouch, 2003). Attractions act as tourism resources of the local community and "key motivators" of the tourists for a specific journey (Leask, 2010). Tourists travel to the destination firstly for exploring, enjoying attractions. And several needs are then emerging. Support services result from the efforts of the destination in creating an in-land consumption environment for tourists. They combine services related to accommodation, transportation, catering, communication and so on (Vegesayi et al. 2009). Support services play a crucial role in delivering the benefits of attractions to tourists (Hu \& Wall,2005). Peoplerelated factors imply all the attributes of the destination, including the staff (knowledge, skills), the tourists themselves (potential risks of health, security ...) and especially local community (hospitality, friendliness ...) that can create favorable or unfavorable perceptions of tourists for the destination (Vegesayi et al., 2009). That then affects their choice of destination. The inclusion of resident attributes in this group demonstrates the increasing recognition of the role of residents/communities in creating and enriching the attractiveness of destinations.

In essence, these attractive attributes act as pull factors that were mentioned by Dann (1977) when explaining the motivations of tourists visiting a destination. In other words, pull factors are the characteristics of a destination that attracts tourists to visit because they will create a unique attraction for destinations that will greatly affect tourist's decision making (Guzel, 2017). Beyond that influence, attractive attributes of a destination were believed to affect the whole behavior of the tourists (Ariya et al., 2017), especially in terms of satisfaction and revisit intention (Um, Chon \& Ro, 2006) as well as the intention to recommend (Eusebio \& Vieria, 2011). Indeed, from the choice-making perspective, some attractive attributes can drive the tourist's evaluation more strongly than the others (Vegesayi et al., 2009) and then gain their final choice. Based on previous studies and adapted from the term "core determinant" (Vegesayi et al., 2009) and "primary attributes" (Laws,1995), "core attractive attributes" introduced in this study can be viewed as destination attributes which act as primary motivation encouraging tourists to visit a specific destination, play the main role in driving tourist's choice-making and constitute the background for the tourism experience in the destination. 
As a primary motivation for a journey, core attractive attribute is supposed to stimulate a desire strong enough to push tourists to travel. It is not necessarily a destination feature arising out first in tourist's minds. But it is definitively the last feature remaining through a screening process in tourist's minds relating to traveling reasons. Said another way, without this feature, traveling to the destination will be less meaningful, or even meaningless. As the main driver of tourist choice, core attractive attribute is abstractedly embodied by the strongest selection criterion of tourist which reflect the most wanted destination feature. This criterion will dominate the tourist's selection process. The core attractive attribute is also the destination feature which is visually perceived most worth to explore. And then, it forms the core component of destination image which influences the next choice. In fact, the strength of these attributes in driving the tourists' choice ranged on a large scale. Some studies revealed destination attributes which play a key role as an attractive source for the tourist's journey, such as natural uniqueness (Ariya et al., 2017), uniqueness of the way of life of the local population and historical attractions (Hu and Ritchie, 1993), natural environment and availability of attractions (Murphy, Pritchard and Smith, 2000). Especially in their study, Vegesayi et al. (2009) asserted that destination attractions are the "core determinants of destination attractiveness" which was confirmed earlier by Formica (2002) and Meinung (1995). In other words, core attractive attributes of a destination are mainly attractions.

As the foundation of tourist's experience, core attractive attribute is obviously tourism resources which constitute the main component of destination products. Based on a sophisticated synthesis of previous studies, Murphy et al. (2000) conceptualised destination products as a combination of two groups of components. The first is service infrastructure including recreation and attraction services, transport services, accommodation services, food services, travel services, and shopping services. And the second is destination environment including the natural environment, political factors, economic factors, technological factor, social and cultural factors. Experience of these component elements will impact tourist perception of tourist's destination experience. The empirical study of Murphy et al. (2000) interpreted the importance of service infrastructure to overall destination experience (both to destination quality perception and trip value perception). These findings indicate that attractions are primary elements to pull visitors to the destination. But this will be not sufficient without appropriate and unique satisfying activities to create an authentic experience for tourists during their visitation. This is also entirely consistent with the classic notion of Jefferson and Lickorish (1988) which assumes that tourism products must be conceptualised from two perspectives: i) a set of physical and service features as well as symbolic associations which are supposed to realise the needs and wants of the tourists and; ii) as satisfying activities at a preferred destination. Thus, while tourist behavior-based rationale contends that in most cases the core attributes are attractions, tourism product-based rationale argues that core attractive attributes are attractions themselves to be value-added through service activities associated with attractions.

It is evident that the more attractive attributes the destination have the more visitors the destination may appeal to. However, it seems that a destination may own several attractive attributes. But the fierce competition between destinations does not give a chance for faded-image destinations. Consequently, destinations have to promote attractive attributes that are really different from competing destinations. In addition, from the destination development planning perspective, destinations must allocate their scarce resources based on determining the importance of attractive attributes (Vegesayi et al., 2009). Therefore, tourism development policymakers of a destination need to identify attractive attributes that can develop sustainable and competitive tourism products. In other words, determine core attractive attributes is really. significant for the planification of the destination's tourism development.

\subsection{Community-based tourism - an approach for sustainable tourism}

Over nearly half a century of development, CBT has also been defined dissimilarly in plenty of scholarly works. Nevertheless, all of these definitions refer to the common spirit that CTB implies community participation in tourism development.

CBT can be defined as "tourism conceived, managed and supplied by the local communities of a given territory" (Terencia, 2018, p.26). In a more comprehensive perspective, CBT was defined as "tourism that is planned, developed, owned and managed by the community for the community, guided by collective decisionmaking, responsibility, access, ownership and benefits" (Tasci et al, 2013, p. 9). CBT builds up its potential through empowering and encouraging the community to be involved in planning, evaluating and controlling resources for tourism development (Giampiccoli, 2018).

Although the term CBT is conceptualised in different ways, it has still three common attributes: community is the main beneficiaries of tourism development, the community is a co-producer of tourism operations and community is a planning maker and supervisor of tourism development of the destination where they live in (Asker et al, 2010).

$\checkmark$ Community is the main beneficiaries: tourism operations are aimed at benefiting the indigenous people, mostly in the rural, mountain region, small town. Tourism is expected to contribute to upgrading their well-being by providing them with the opportunity to create by themselves a stable revenue flow, to up-skill in traditional 
production and service operation, to reserve their tradition social-cultural values.

Community is the co-producer: a tourism product is "a combination of tangible and intangible elements, such as natural, cultural and man-made resources, attractions, facilities, services and activities around a specific center of interest which represents the core of the destination marketing mix and creates an overall visitor experience including emotional aspects for the potential customers" (UNWTO). Normally, these facilities, services, and activities are offered by tourism businesses. In CBT, communities will take part in the tourism value chain by delivering the service to tourists either as an independent product or as a component of the package product offering by professional tourism businesses.

$\checkmark$ Community is the planning-maker and supervisor for tourism development: it is thought that only if community participation is implemented at the very beginning of tourism development is it really effective. The attendance of external entities is to facilitate that participation. Communities must decide how the tourism resources at their destination must be exploited, to what extent is appropriate. They must also be involved in setting objectives of tourism development as well as controlling the achievement of these objectives.

Principles for a successful CBT always highlight community participation (Tasci et al, 2013; Goodwin and Santilli, 2009). According to Pretty (1995), there are 7 types of community participation. The lowest level is "Passive participation" where the community just gets information about what is going happen or already happened. Participation is in form "Information giving" when the community participates in answering questions concerning tourism development without the possibility to influence the findings. "Participation by consultation" is a higher level of participation when the community's attitude, suggestions are taken into account by the external parties when they make solutions. "Participation for material incentive" is a type of participation in which the community provides its resources such as human resources and facilities for tourism operations and in return cash and other material incentives. In "Functional participation", community participation is more co-operative and collaborative by forming groups/committees. But the dependence on external parties is still considerable. "Interactive participation" is characterized by more involvement of the community in the decision-making and control of the CBT venture. The highest level of the community's participation is self-mobilization in which the community dominates the whole process of CBT development, from the initiating stage to the controlling stage. Besides this typology, Tosun (2006) suggested another typology of community participation. He defined three levels of participation as coercive participation, induced participation, and spontaneous participation. Spontaneous participation is bottom-up participation. It means that participation is initiated by the locals. Consequently, they make the decisions and control the decision realization. Participation is thus active and authentic. Both induced participation and coercive participation are top-down in which the participation is directed by external parties. However, the community has more choices for their participation in the "induced" type than "coercive" type. Ordinarily, communities are heterogeneous (Blackstock, 2005). Thus the different groups will have different expectations when participating. That results in the conflict between each other (Tosun, 2006). The higher the participation level is, the more involved does the community gets in the role of an employee, employed manager, owner, and initiator. As a result, the community engages more in the decision-making process. Inspired from Pretty's and Tosun's typology of community participation, Tasci et al. (2013) suggested a more functional grouping of community-participating activities which are categorised in three groups: providing information for tourism developers; participate in the decision-making process; and providing tourist services as employees, employed managers, and owners. Each category of participation shapes the more specific role of the community in the tourism development and subsequently, participating activities can be deduced. This paper just refers to community participation in providing tourist services. Said another way, in this type of participation, the locals play the role of co-producer for the destination's tourism product. Their tourism service outcomes and possible tourism professionals' service outcomes will work together to complete the tourist's experience of the destination. The coherence between these component elements is crucial for a typical CBT destination's image.

Although community participation in tourism is very core of CBT, there are conceptual as well as practical arguments about constraints to this participation (Tosun, 2000; Scheyvens, 2002). According to Tosun (2000), there are 3 kinds of constraints to community participation. The first relates to the operational level: high centralization of tourism administration and lack of coordination between potential stakeholders which makes community involvement more difficult. The second includes structural limitations that originated from the asymmetric relationship between tourism professionals and the community. Tourism professionals are unwilling to negotiate with the community or community are not likely in the position to negotiate with them properly. That is induced by the fact that the community frequently lack relevant knowledge, human and financial resources. The third is a set of cultural constraints. The community may have low awareness of the social-cultural, economic and political consequences of tourism development. And they may then find unnecessary to participate in tourism development. It means that the local participation is usually supposed to be high in CBT, this is not always the case (Breugel, 2013).

While community participation is considered as the nature of CBT, the presence of external parties in the formation and development of CBT ventures is also postulated (Ruiz-Ballesteros and Brondizio, 2013; 
Giampiccoli, 2017). There are three questions concerning the presence of external parties to be elucidated: Why external parties' participation is essential? Who are they? and What their roles should be for CBT ventures to succeed sustainably?

An idea rooted from various typologies of community participation as mentioned above is that, in general, the community can participate in three groups of activities: providing information for tourism developers; participate in the decision-making process; and providing tourist services as employees, employed managers and owners (Tasci et al, 2013). In fact, the number of failed CBT ventures is not trivial at all (Goodwin and Santilli, 2009) even though community involvement is always the core of those ventures. The problem is that the community was not strong enough to fulfill its role in the manner they were expected to ensure the feasibility and longevity of the CBT venture. Ordinarily, CBTs are often carried out within underprivileged, isolated, or disadvantaged communities. And their inherent weaknesses are the lack of tourism knowledge and tourism business, communication skills with tourists, management skills, market access experience, and financial resources for setting up tourism facilities or even for transforming their household-purposed facilities to tourism-purposed facilities (Okazaki, 2008; Goodwin \& Santilli, 2009; Tasci et al, 2013; Giampiccoli, 2018). That makes then these communities frequently face challenges in partaking tourism operations (Giampiccoli, 2018). Consequently, external support is then crucial in CBT practice (Ruiz-Ballesteros \& Cáceres-Feria, 2016). The presence of external parties is advocated to compensate for the above deficiencies or more precisely to facilitate the community to strengthen their capability of participating in or even of self-mobilizing tourism development in their destination (Giampiccoli, 2018; Luchetti \& Font, 2013). Also, it is unfair to say that CBT only benefits the community at the CBT destination. CBT also helps to conserve natural diversity, cultural diversity, and ensure an overall socioeconomic-cultural balance for an entire destination, even the whole country (Tasci et al, 2013; Luchetti \& Font, 2013). Therefore, undertaking CBT development is not the responsibility of the only community. Governmental entities, as well as interested entities, should be getting involved. In fact, the private sector, specifically tour operators, also derive economic benefits from CBT. In that case, the cooperation of that kind of stakeholder with the community is a win-win one.

External parties in CBT are often categorized in 3 groups of entities. The first group includes governmental organizations. The second group is composed of donor organizations and NGOs. And the third group incorporates entities from the private sector. Effective and authentic collaboration between these actors with the community will be one of the key factors of successful CBT (Tasci et al, 2013; Luchetti \& Font, 2013; Goodwin and Santilli, 2009). In fact, the presence of external parties may be at both initiating, implementing and controlling stages of a CBT venture. At the initiating stage, the community needs a change of awareness of tourism, ideas of tourism development for them and the next generation. External parties can act as initiators and educators/trainers. In the implementing stage, the community needs improvement, enhancing their knowledge and skills concerning holding tourism operations, their product's market accessibility, their financial resources ... In other words, the community needs relevant methods, instruments for carrying out the CBT by themselves. In that case, the facilitator and collaborator are the crucial roles that external parties can take. In the controlling stage, the community needs effective evaluation criteria and a well-structured mechanism of monitoring. The collaborator role has still full meaning besides an equally significant role as the supporter. (Giampiccoli, 2018; Tasci et al, 2013, Guzman et al, 2011; Okazaki, 2008).

In a literature-review effort, Tasci et al (2013) susggested a synthetized framework for external parties:

Table 1: Roles of external parties in a CBT venture

\begin{tabular}{|l|l|}
\hline \multicolumn{1}{|c|}{ External actors } & \multicolumn{1}{c|}{ Roles } \\
\hline $\begin{array}{l}\text { Governmental } \\
\text { Organisations }\end{array}$ & $\begin{array}{l}\text { Leader as visionary, policy-maker, regulator, coordinator, facilitator, guide, and controller } \\
\text { - providing policy, finance, knowledge, experience, and know how; educating, training } \\
\text { and empowering locals to achieve equity in participation, decision-making, ownership } \\
\text { and distribution of costs /benefits }\end{array}$ \\
\hline $\begin{array}{l}\text { Donor } \\
\begin{array}{l}\text { Organisations and } \\
\text { NGOs }\end{array}\end{array}$ & $\begin{array}{l}\text { Supporter as facilitator, guide, trainer - providing financial resources, knowledge, } \\
\text { experience and know how; educating, training locals for equity }\end{array}$ \\
\hline $\begin{array}{l}\text { Entities from } \\
\text { private sector }\end{array}$ & $\begin{array}{l}\text { Supporter as partner, developer, investor, facilitator, guide and beneficiary - providing } \\
\text { finance, knowledge, experience, and know how; educating training and employing locals }\end{array}$ \\
\hline
\end{tabular}

Source: Tasci et al, 2013, p. 21

In fact, the roles of the external parties are diversified authentically and correspondingly to top-down or bottom-up approach that drives the community participation (Breugel, 2013; Giampiccoli, 2018). Therefore, notwithstanding the uncontroversially important and identified roles of the external parties, there is not a one-fitall framework applicable to every CBT venture. CBT developers are supposed to well defined how active intervention and what detailed functions the community can partake in tourism development. As a result, different potential external parties will be determined and encouraged to be on the scene. However, only if the external parties have appropriate knowledge, expertise and skills related to CBT development as well as properly equipped, 
can they undertake their role in an expected manner (Giampiccoli, 2018). And according to Giampiccoli (2018) once again, while external parties' participation is generally time-bound, engagement of the governmental organizations is expected more long-term. The main reasons are the pervasive benefits of the CBT venture and the greater advantages that governmental entities usually have compared with other external actors.

Sustainable tourism can be seen as a form of tourism development in the direction of basing tourist satisfaction on three pillars: conserving the resources of the natural environment, preserving cultural-social values of the local community and ensure long-term economic benefits for stakeholders - from tourism businesses, workers, investors to local communities (UNEP \& UNWTO, 2005). An authentic CBT venture is supposed to be sustainable in nature. In others words, a CBT practice has been demonstrated economically sustainable (in terms of job opportunities, long-term greater income for stakeholders...), environmentally sustainable (in terms of contribution to conserving the natural environment) and socially-culturally sustainable (in terms of empowerment of the community, conserving the identity...) (Dangi and Jamal, 2016). So, in a CBT practice, the core of the tourism development strategy is the development of a sustainable tourism product (Ellis, 2011) that has a long-term appeal, does not harm the locals' habitat, while ensuring financial viability for all stakeholders. At a typical CBT destination, local lifestyle, folklore and culture, materials and clothing, dance and music food and drink, and the natural surroundings all can become the CBT products (Tasci et al, 2013). By raising the resident community's awareness about the conservation of these resources, and training the community to make these resources more unique, more competitive, the sustainability of the products will be promised.

\subsection{Community-based tourism and destination attractiveness}

In terms of commercial viability, CBT has to be authentically appealing to tourists. One of the critical predictors is the uniqueness of destination products (Luchetti \& Font, 2013). This uniqueness is originated from a core attractive attribute and enriched by the community participation in making tourists perceive benefits conveyed by this core attractive attribute. As argued above, core attractive attributes are mostly attractions. A tourism attraction is defined as 'a permanent resource, either natural or human-made, which is developed and managed for the primary purpose of attracting visitors' (Hu \& Wall, 2005, p.619). There are different classifications of attractions introduced in the literature, including that of Crouch and Ritchie (1999). In this classification, attractions are categorized into six groups: physiography, culture and history, market ties, activities, events, and tourism superstructure. Attractions play a crucial role in the destination's choice because they are the core elements of a destination's appeal which acts as a principal factor motivating tourists to visit a destination (Ritchie \& Crouch, 2003). So, CBT can be initiated from these kinds of attractive attributes. At some destinations which own natural resources, CBT could be developed base on exploiting them with the participation of communities in some activities. Even if destinations are not endowed by nature or heritage, they may have still opportunities of attracting tourists with authentic and creative man-made attractions (Emir, Bayer, Erdoğan \& Karamaşa, 2016). It means that the resident community can participate in creating man-made attractions with their cultural buildings, cultural events ... Said another way, CBT its turn can make a destination more special.

Besides, support services like transportation, accommodation, catering, communication, travel services are so essential because they influence accessibility and responsiveness of tourism destinations. These services facilitate a destination's development as well as play the role of standards of that development (Vegesayi et al., 2009). Normally, these services are delivered by professional tourism businesses. López-Guzmán et al. (2011) pointed out that communities in developing countries were often involved in providing accommodation, food, guide service, and selling local products. When the resident community gets involved in these operations, services will be made up of local identity which makes the destination more differentiated, more impressive.

Finally, people-related factors include staff-related factors, tourist-related factors, and resident-related factors. CBT is sometimes attractive in that the locals are the staff. Their advantages are a deep understanding of the attractions' values, naturally revealing the indigenous cultural identity in service style. Vegesayi et al., (2009) also noted that the locals as employees of the tourism and hospitality industry may affect a destination's attractiveness. Besides, social interaction between tourists and residents is believed crucial in attracting people to travel to the destination (Smith, 2000). Local elements which constitute CBT product are inherently exotic, different, enriching, especially when "bundled with the genuine enthusiasm, warmth, and hospitality of the hosts, creating a unique social space for cross-cultural expression and exchange". (Tasci et al, 2013, p 11).

As more and more tourists travel responsibly, the sustainability of a tourist destination significantly impacts their destination choice (Budeanu, 2007). Obviously, a typical CBT destination reveals the full potential of sustainability. Community-based attractive features are believed to create long-lasting attractiveness toward tourists, especially sustainable tourists.

\section{Methodology}

The idea of this paper was stemmed from the author's participation in a CPT project in Dienphuong, a sub-district of district Dienban (near ancient town Hoian, Quangnam Province, Vietnam) five years ago. One of the questions 
that the project had to answer is how Dienphuong could develop CBT without outstanding attractions like Hoian except for typical rural setting and lifestyle. In seeking a pattern for CBT development in Dienphuong, the author has case-studied some successful practices of CBT in the destinations which had the same context as Dienphuong in terms of attractiveness. And the findings revealed community-based-tourism activities that could be implemented based on the so-called destination's "core attractive attribute" and some efforts they could make Dienphuong more attractive to the tourists.

After this project, other questions arose: which "core attractive attributes" that CBT could be initiated from and how CBT can make the destination more attractive in terms of offering visitor's experience and community involvement in creating that experience. The study has been continuously developed with the same approach: casestudy approach.

Actually, CBT practices are frequently located wide-geographically and demonstrated in a long duration. Field survey is then extremely challenging. So documentary research was carried out. Firstly, essential data was collected from scholar works on CBT and then data from the website of CBT destinations, the website of CBT projects and the website of international organizations supporting CBT projects were used to verify, if available. For two CBT ventures in Hoi An, Vietnam, field surveys were implemented because of better physical accessibility. In these surveys, observation and unstructured personal interviews were proceeded, concerning the two above questions.

There are many CBT practices all over the world and this research have qualitative feature. So the purposive sampling was used. The choice of which CBT practices for the research, both by field surveys and documentary research, is based on the following criteria:

Sustainable viability: the selected CBT practices are supposed to have lasting tourist appealing, improve continuously the livelihood of the community, encourage the long-term participation of the community. The sustainable viability of CBT practices is recognised and documented. It means that in numerous works of literature on CBT, just CBT ventures that are assessed "successful" or "good practice" are entered in the shortlist.

Research accessibility: multi-channel information accessibility was examined for fully understanding what the destination's core attractive attributes are and how the project has been initiated as well as implemented. Because the most important objective of the paper is to clarify how CBT can make the destination more attractive, the community's participation as a co-producer for tourism products is required to be fully understood. Thus, only CBT practices whose details about that community role are documented can be selected to study.

Definition of destination: online search results show that many scholar works on CBT studied for a country, a multi-nation region as CBT destinations. These studies will be filtered out from the research in this paper because this paper addresses only destinations defined local entities such as cities, towns, village, region areas (Lew \& McKercher, 2006).

Frequently, qualitative research requires a smaller sample size than quantitative research. According to Morse (1994), an effective sample size should be 30-50 while Creswell (1998)' suggestion is 20-30. Then, after the screening process, $30 \mathrm{CBT}$ practices that best meet the above criteria were selected, then investigated and analyzed.

The data analysis includes 3 steps:

Step 1: identifying these destinations' core attractive attributes on which CBT has been initiated, then grouping CBT practices according to the core attractive attributes,

Step 2: verifying these core attractive attributes falling in which factors of destination attractiveness and possibility of creating the core attractive attributes by the community

Step 3: clarifying other factors of destination attractiveness that CBT can promote.

\section{Study results and analysis}

4.1. Five types of core attractive attributes on which CBT is frequently developed

CBT is practiced all over the world, but the most successful CBTs which pull the attention of many stakeholders are mostly in developing or least developed countries. Investigating these 30 good CBT practices revealed that there are five core attractive attributes that CBT might be based on. They include a unique event, a special tourist route, a craft village or an agro village, a conservation area or a world heritage or national heritage and rural landscape and lifestyle. 
Table 2: Types of core attractive attribute on which CBT is frequently based on

\begin{tabular}{|l|l|}
\hline $\begin{array}{c}\text { Type of core attractive } \\
\text { attribute }\end{array}$ & \multicolumn{1}{c|}{ CBT practices based on } \\
\hline A unique event & $\begin{array}{l}\text { The Huong Pagoda Festival in Vietnam (Vu, 2014), The annual Rockstone Fish } \\
\text { Festival in Guyana (Guyana Government Information Agency, 2014) }\end{array}$ \\
\hline A speacial tourist route & $\begin{array}{l}\text { Ruta de la Flores, El Salvador (López-Guzmán et al,, 2011), the Meket CBT project } \\
\text { (Journeys by design, 2015), African Ivory Route in Limpopo, South Africa (Southern } \\
\text { Africa Tourism Service Association and European Union, 2020), Ruta del Café, } \\
\text { Dominican Republic (Caribean Tourism Organisation and European Commission) }\end{array}$ \\
\hline $\begin{array}{l}\text { A craft village/agro } \\
\text { village }\end{array}$ & $\begin{array}{l}\text { Ccaccaccollo Village, Peru (Luchetti \& Font, 2013), Thanh Ha Pottery Village, Tra } \\
\text { Que Vegetable Village (both in Hoi an, Vietnam), Kahawa Shamba, Tanzania } \\
\text { (Goodwin \& Santilli, 2009), Grand Fond Village, Dominica (Caribean Tourism }\end{array}$ \\
\hline $\begin{array}{l}\text { A conservation } \\
\text { area/world } \\
\text { heritage/national } \\
\text { heritage }\end{array}$ & $\begin{array}{l}\text { Palawan, Philippines (Okazaki, 2008), Morne Trois Pitons National Park, Dominica } \\
\text { (Berry-Fingal, 2009), Bario, Malaysia (Asker et al., 2010), Annapurna, Nepal (Lama, } \\
\text { 1999), Argyle Fall, Trinidad and Tobago (Caribean Tourism Organisation and } \\
\text { European Commission), Buhoma, Uganda (Goodwin \& Santilli, 2009), Karen } \\
\text { Mogensen Reserve, Costa Rica (Goodwin \& Santilli (2009), Khama Rhino Sanctuary } \\
\text { Trust, Botswana (Sebele, 2010), Casa Machiguenga in Manú National Park, Peru } \\
\text { (Goodwin \& Santilli (2009), Pulau Pedang, Malaysia (Abukhalifeh \& Wondirad, } \\
\text { 2019), Tamaki Maori Village Rotorua, New Zealand (Ryan \& Pike (2003), Tumani } \\
\text { Tenda, Gambia (Betz (2000), Banteay Chhmar, Cambodia (Ellis (2011), Il Ngwesi, } \\
\text { Kenya (Manyara \& Jones (2007) }\end{array}$ \\
\hline $\begin{array}{l}\text { Rural landsape and } \\
\text { lifesty }\end{array}$ & $\begin{array}{l}\text { the Homestay program in Ban Talae Nok, Thailand (Dolezal (2011), The Endogenous } \\
\text { Tourism Project, Kerala India (Mody (2011), One Life Japan (Asker et al., 2010), } \\
\text { Seongeup Folk Village, Korea (Korea Tourism Organisation), Jaringan Ekowisata } \\
\text { Desa, Indonesia (Byczek, 2011) }\end{array}$ \\
\hline
\end{tabular}

From destination attractiveness view-point, findings from these CBT practices indicate that all core attractive attributes are attractions. It is common with the assertation of Ferrario (1979) and Crouch and Ritchie (1999) that attractions are the first predictors for destination attractiveness. Some attractions originally appeared and existed naturally not for tourism purposes but over time have been promoted for tourism development (conservation area, world and national heritage, craft village, rural lifestyle, unique event). While others are intendedly developed in early for tourism development goals (unique event, special tourism route). In other words, the community, with the support of external parties, can actively create a core attractive attribute for tourism development in their destination - an effective new tourism product for less developed parts within a country. They are even part of the attractions of the destination. Moreover, this is also a way of diversifying products for niche market segments on a more macro scale (Tasci et al, 2013). It is worth noting that the attractions - as core attractive attributes - in those CBT practices are characterised by i) need to be preserved and ii) located within or beside underprivileged communities. Thus they need a sustainable approach in exploiting.

Studies on these CBT also revealed that when these core attractive attributes were promoted to the tourism market, they encouraged strongly the tourists to the destination. In other words, they created key motivators for tourists traveling to the destination: uniqueness of the event's rituals, event's atmosphere, an exciting trekking, nostalgic feelings, conserved values, natural and cultural uniqueness...Furthermore, these core attractive attributes were conveyed to tourists' perceptions through community-based activities. Those are ritual and festival activities for CBT evolved from a unique event, sightseeing and exploring for CBT developed along a special tourist route, learning about traditional value-chain for CBT developed within a craft village/an agro village, learning and sightseeing for CBT associated with a conservation area/a world heritage/a national heritage, and enjoying daily life and rural scenery for CBT associated with rural landscape and lifestyle. These activities can be seen as core tourism activities in these destinations' products named by Murphy et al. (2000) as "attraction services".

\subsection{How can CBT make the destinations more attractive?}

Case studies also claim that different core attractive attributes definitively create different tourist experiences that are embodied by tourist activities. Accordingly, community-based activities are not the same respectively different destinations. Notwithstanding that difference, these activities are of the same purpose that facilitates the tourists completely enjoy the core attractive attributes. It means that CBT - which characterised by the participation of the community as co-producer for a destination's tourism products - can make a destination more attractive by making attractions, support services, and people-related factors become indigenous.

Proclamation of López-Guzmán et al. (2011) about community participation in providing support services was evidenced lively in these CBT ventures. Offering grassroot accommodation and local cuisine seems the most 
frequent support services that communities can partake. These kinds of community participation were found in 23 CBT ventures (in total 30 studied CBT practices). In this case, the differentiation between CBT destinations is established not on the kind of services but on the physical manifestation of services. For example, enjoyment of homestay in an ancient house in One Life Japan is certainly different from homestay in a lodge Casa Matsiguenka - right in the middle of Amazon. In providing these services, the locals show naturally and smoothly local lifestyle. However, the most significant contribution of the community to destination attractiveness is providing indigenousfeatured travel services. Local guide service, traditional song and dance performance, traditional games performance, helping tourists learn about the rich flora and fauna, collecting wild vegetables with tourists...which creates a really exclusive experience for tourists in these CBT destinations. Selling local handicrafts, local products as souvenirs is also a popular choice of community because of the simplicity in operation as well as the highdemanding feature of this kind of service. It is evident that the communities seem to have more chances to make the destination attractive by offering support services than innovating attractions.

Although tourism professionals also partake in some CBT practices, the community still takes a key role in providing attraction services and support services. In 30 selected CBT practices, local identity and hospitality were promoted proudly. That people-related aspect really made destinations such as Tamaki Maori Village, Thanh Ha Village, Ban Talae Nok, Buhoma, Bario...more exclusive.

\subsection{Further discussions}

It is evident that the success of a CBT venture partially rooted in destination attractiveness but it is the community participation itself-as a co-producer for destination's products, has a great contribution to destination attractiveness. In fact, there are three kinds of tourism-product-creating activities that communities can partake as co-producer. The first kind consists of activities that primarily rely on natural and historic assets (for example, tour guiding, instructing tourists to learn about the conservation...). The second kind comprises activities that principally require the locals' knowledge and skills (for instance, practicing rituals and organizing festival activities, instructing tourists to participate in some production activities, showcasing traditional activities...). And the third includes activities that resort to physical as well as unphysical assets of the locals (offering homestay and local foods, selling souvenirs and other goods, hiring out means of transport, driving/riding tourists...). In these activities, the community can engage in as an employee or/and employer. Clearly, these CBT practices are longterm viable because it creates not only low profile jobs but also high profile jobs for the locals. Unfortunately, for locals who bypass a change process in production and consumption through industrialization, they may encounter obstacles of transition from agrarian to service production (Pinel, 2013). Those obstacles will impair the community involvement in tourism development, moreover, weaken people-related factors of destination attractiveness... And although Tasci et al (2013, p. 11) believe that should the CBT development be based on existing knowledge systems, the traditional way-of-life, and practices, existing community capital, skills, cultural and environmental assets, it will be carried out more favorable. But that does not mean that an improvement of or providing resources for the community is not called for. This entails an essential improvement of the community's tourism knowledge, resources, skills. Consequently, partnering with external parties is necessary and advantageous (Tasci et al, 2013).

\section{Implications and conclusion}

CBT is believed to keep on proliferating all over the world. The feasibility and longevity of a CBT venture are always aimed at by the CBT developers. An elucidation the mutual relationship between CBT and destination attractiveness, both on theoretical and practical perspective, leads to some implications.

Firstly, a CBT venture should be initiated by determining the core attractive attribute of the destination. This core attractive attribute is supposed to be potential for activities that are likely operated or even owned by the community. It would be best if the community itself do that, but if not possible, external parties' intervention could begin at this first stage. The determination of core attractive attributes needs to be expanded to identifying activities that can exploit or interpret these core attractive attributes to visitors. Furthermore, innovating or diversifying core attributes is a way to innovate tourism products of a destination in general and CBT destinations in particular. And if in fact, some new kind of CBT-potential core attractive attribute appear it means that a new type of CBT development can be promoted.

Secondly, a CBT venture is always expected to be commercially, ecologically and socially viable. This depends not only on how attractive the core attribute is toward enough big number of tourists but also depends on the level that the community-nature of supporting services and people-related factors meet the overall service expectation of CBT tourists. Besides, that viability is also a consequence of the fact that all participants, including the community, recognise that their participation is worthwhile. In most cases, the communities need the support to determine what activities they can participate in and what are subsequent requirements. And the role of a supporter of the external parties is significant. In fact, when the community has a sense of ownership of CBT in their destination, they will try to come to the end of all activities. But the requirements imposed on the community 
will also be very high to get that ownership. In this case, the facilitation of the external parties is critical if the community calls for external funding, improvement of business skills and market accessibility of their tourism products.

Thirdly, among imposed-to-community requirements for CBT development, human efficiency-related requirements are the most fundamental. Whether the community participates as an employee, paid managers or owners, the pertinent knowledge and skills are always crucial for authentic empowerment (Tasci et al., 2013). There are two approaches to establish educational systems for CBT application. In the first approach, resources for the training system are mobilized from external actors such as governmental organizations, donor organizations, NGOs, and even the private sector. Advantages of such an educational system are updated and experience-based knowledge and skills. The resources are also more abundant thanks to the cooperation of many parties. While, in the second approach, resources for education are rooted in the community themselves. This kind of system is more advantageous than the first one in terms of they transmit tourism knowledge and skills by their own "indigenous voice". Moreover, this system is more available because educational resources are right within the community that is both spatially and temporally convenient. For a long-lasting CBT venture, the first system will be critical in the initiating stage but for later stages, the second system has to play the key role.

As such, for initiating a CBT venture, CBT practitioners have to determine the core attractive attribute on which CBT can be developed sustainably. That core attractive attribute will become the key motivator for tourists' visitation to the destination. Furthermore, the study of thirty selected CBT practices reveals that that core attribute is the core component of destination image which influences tourist flow to these destinations. In turn, CBT for its part also contributes to making destinations more intriguing through community participation in providing tourism services. Thirty studied CBT practices are a vivid demonstration of the significance of community participation in differentiating tourism products across the destinations. Consequently, the CBT practitioners are supposed to ascertain at what service-offering activities that community can partake so that both creating a unique identity and not posing too many challenges in terms of resources.

Finally, this paper could only study thirty typical CBT practices which were recognised as successful and data-accessible. From the analysis of these thirty CBT practices, the five types of core attractive attributes on which CBT can be developed are identified. That also helps to delineate corresponding types of CBT development. But it is believed that types of grounding-for-CBT core attractive attributes may be more diversified if research is geographically and numerically expanded. Furthermore, the paper just examines the relationship between CBT and destination attractiveness from the qualitative approach. Thereupon, there is still wondering thinking about whether the relation between the level of community participation and destination attractiveness can be quantified from tourist perceptions. This question suggests further study.

\section{Acknowledgement}

The author was very grateful to residents of two villages Thanh Ha and Tra que to guide her for a village-tour and give her valuable information about CBT in their villages

\section{Disclosure statement}

The authors declare no conflict of interest

\section{References}

1. Abukhalifeh, A. N. \& Wondirad, A. (2019). Contributions of community-based tourism to the socio-economic well-being of local communities: the case of Pulau Redang Island, Malaysia. International Journal of Tourism Sciences, 19:2, 80-97

2. Ariya, G., Whishitemi, B. \& Sitati, N. (2017), Tourism Destination Attractiveness as Perceived by Tourists Visiting Lake Nakuru National Park, Kenya. International Journal of Research in Tourism and Hospitality (IJRTH), Volume 3, Issue 4, 2017, 1-13

3. Asker et al. (2010), Effective Based Community Tourism: A best practice manual. Sustanable Tourism Cooperative Research Centre 2010.

4. ASEAN (2016). ASEAN Community-based Tourism Standards, 2016. Online available https://www.asean.org/storage/2012/05/ASEAN-Community-Based-Tourism-Standard.pdf (Jully 20 2018)

5. Berry-Fingal, B. (2009). Warmmae Letang: A case study of community-based tourism within the Morne Trois Pitons World Heritage Site, Dominica, CANARI Technical Report No 384.

6. Betz, K. (2000). Award Winner: The Village Community Project: TUMANI TENDA ECO-TOURISM CAMP, Award Rationale of TO DO!2000. Online available http://www.todo-contest.org/eng/awarded-projects/to-do2000-tumani-tenda-eco-tourism-camp-gambia/ (March 21 2020)

7. Blackstock, K. (2005), A critical look at community based touris, Community Development Journal 40(1), 3949.

8. Breugel, L.V. (2013). Community-based tourism: Local participation and perceive inpacts_A comparative 
study between two communities in Thai Land. Master Thesis, Radboud University Nijmegen.

9. Budeanu, A. (2007). Sustainable tourist behavior - a discussion of opportunities for change, International Journal of Consumer Studies, 31(5):399-405

10. Byczek, C. (2011). Blessings for all? Community-based ecotourism in Bali between global, national, and local interests - A case study. Austrian Journal of South-East Asian Studies, 4(1), 81-106

11. Caribean Tourism Organisation and European Commission. Good Practices in Community-Based Tourism in the Caribbean. Carl Bro Intelligent Solutions. Online available at https:/www.onecaribbean.org/wpcontent/uploads/CompetingWithTheBestWORDGoodPracticesCBTENG.pdf, (January 30 2020)

12. Creswell, J. W. (1998). Qualitative inquiry and research design: Choosing among five traditions. Thousand Oaks, CA: Sage Publications

13. Crouch, G., \& Ritchie, B. (1999). Tourism, competitiveness, and societal prosperity. Journal of Business Research, 44, 137-152.

14. Dann, G.M.S. (1977). Anomie, Ego-Enhancement and Tourism. Annals of Tourism Research, 4 (4), 184-94.

15. Dangi, T.B. \& Jamal, T. (2016), An integrated approach to "Sustainable community-based Tourism", Sustainability, 8 (5): 475

16. Dolezal, C. (2011), Community-Based Tourism in Thailand: (Dis-)Illusions of Authenticity and the Necessity for Dynamic Concepts of Culture and Power. Online available https://www.researchgate.net/publication/289335325_Community-Based_Tourism_in_Thailand_DisIllusions_of_Authenticity_and_the_Necessity_for_Dynamic_Concepts_of_Culture_and_Power (March 28 2020)

17. Ellis, S. (2011). Community-based tourim in Cambodia: Exploring the role of community for successful implementaion in least development countries, Doctor of Philosophy Thesis, Edith Cowan University

18. Emir, O., Bayer, R. U., Erdoğan, N. K. \& Karamaşa, C. (2016), Evaluating the Destination Attractions from the Point of Experts' View: An Application in Eskişehir, TURIZAM Volume 20, Issue 292-104

19. Estevão, C. M., Garcia, A. R. B. \& De Brito Filipe, S. M. I. F. (2015), What are the Most Critical Factors for Competitiveness of a Tourism Destination? Online available https://www.igi-global.com/chapter/what-arethe-most-critical-factors-for-competitiveness-of-a-tourism-destination/130523, (February 012020 )

20. Eusebio, C. \& Vieira, A. L. (2011). Destination Attributes' Evaluation, Satisfaction and Behavioural Intentions: A Structural Modelling Approach. International Journal of Tourism Research, 15(1), 66-80

21. Ferrario, F. (1979). The evaluation tourism resources: an applied research (Part 2), Journal of Travel Research 17(4), 24-30

22. Formica, S. (2002). Measuring destination attractiveness: A proposed framework. Journal of American Academy of Business, 1(2), 350-355.

23. Formica S \& Uysal M. (2006). Destination attractiveness based on supply and demand evaluations: An analytical framework. Journal of Travel Research 44: 418-430

24. Giampiccoli, A. (2018). Community-based tourism development model and community participation, African Journal of Hospitality, Tourism and Leisure, Volume 7 (4) - (2018)

25. Goodwin, H. \& Santilli, R. (2009). Community-based tourism: a Success?. Available at http://www.haroldgoodwin.info/uploads/cbtasuccesspubpdf.pdf, [Retrieved March 28 2015)

26. Guyana Department of Public Information. Annual Fish festival. Online available https://dpi.gov.gy/tag/fishfestival/ (March 23 2020)

27. Guzel, B. (2017). Destination attributes in the eye of the local peoples, Kastamonu Üniversity. Journal of faculty of Economics and Administrative Sciences- Volume 18, Issue 1, ICEBSS 2017 Special Issue

28. Hu, Y. \& Ritchie, B. (1993). Measuring destination attractiveness: A contextual approach. Journal of Travel Research, 25-34.

29. Hu, W. \& Wall, G. (2005). Environmental Management, Environmental Image and the Competitive Tourist Attraction. Journal of Sustainable Tourism 13(6):617-635

30. Jefferson, A.\& Lickorish, L. J. (1988), Marketing tourism. A practical guide. Longman Group UK Ltd

31. Journeys by Design (2015), Meket Community Tourism Walk. Online avaliable http://www.journeysbydesign.com/destinations/ethiopia/lalibela/meket-community-tourism-walk, (May 04 2015)

32. Korea Tourism Organisation, Seongeup Folk Village. Online available https://english.visitkorea.or.kr/enu/ATR/SI_EN_3_1_1_1.jsp?cid=264205 (February 28 2020)

33. Krešić, D. \& Prebežac, D. (2011). Index of destination attractiveness as a tool for destination attractiveness Assessment. Tourism, Vol 59, No4, pp 497-517,

34. Lama, W.B. (1999). Valuing women as assets to community-based tourism in Nepal. Cultural Survival Quarterly, 23(2)

35. Laws, E. (1995). Tourist Destination Management Issues, Analysis and Policies. London: Routledge

36. Leask, A. (2010). Progress in visitor attraction research: Towards more eff ective management, Tourism 
Management, 155-166.

37. Lew, A. \& McKercher, B. (2006). Modeling Tourist Movement-A local destination analysis, Annals of Tourism research, Vol. 33, No 2, pp 403-423

38. López-Guzmán, T. et al. (2011). Community-based tourism in developing countries: a case study, Tourismos: an international multidisciplinary Journal of Tourism, Vol 6, No.1, Spring 2011, tr 69-84

39. Luchetti, V.G. \& Font, X. (2013). Community-based tourism: critical success factors, Available at : http://www.icrtourism.org/wp-content/uploads/2012/03/OP27.pdf, [Retrieved March 28 2015]

40. Manyara, G. and Jones, E. (2007). Community-Based Tourism Enterprises Development in Kenya: An Exploration of Their Potential as Avenues of Poverty Alleviation, Journal of Sustainable Tourism, 15, 628644

41. Meinung, A. (1995). Determinants of the attractiveness of tourism region. In S. F. Witt \& L. Moutinho, (Eds.), Tourism marketing and management handbook. Hertfordshire, Prentice Hall.

42. Mody, M. (2011). A Model for Integrated Sustainable Tourism Development in Developing Countries: The Case of Rural Tourism in India. Online available http://scholarworks.umass.edu/cgi/viewcontent.cgi?article=1061\&context=gradconf_hospitality, (March 28 2015)

43. Morse, J. M. (1994). Designing funded qualitative research. In Denizin, N. K. \& Lincoln, Y. S., Handbook of qualitative research (2nd Ed). Thousand Oaks, CA: Sage

44. Murphy, P., Pritchard, M. P. \& Smith, B. (2000). The Destination Product and Its Impact on Traveler Perceptions. Tourism Management, Vol. 21, No. 1, 2000, pp. 43-52.

45. Okazaki, E. (2008). A Community-Based Tourism Model: Its Conception and Use. Journal of Sustainable Tourism, Vol 16, No 5, 2008, tr 511-528

46. Pinel, D.D. (2013). Create a good fit: A community-based Tourism Planning Model. Online available https://pdfs.semanticscholar.org/ee4c/cdfba871faa55db07e80950300f75672cf89.pdf, (March 22 2020)

47. Pretty, J. (1995), Participatory learning for sustainable agriculture, World Development 23(8), 1247-1263

48. Ritchies, J.R.B. \& Crouch, G.I (2003). The competitive destination - A sustainable perspective, CABI Publishing.

49. Ruiz-Ballesteros, E. \& Cáceres-Feria, R. (2016), Community-building and amenity migration in communitybased tourism development. An approach from southwest Spain, Tourism Management, 2016, vol. 54, issue C, 513-523

50. . Ryan, C. \& Pike, S. (2003). Maori-based tourism in rotorua: Perceptions of place by domestic visitors, Journal of Sustainable Tourism, 11(4)

51. Sebele, L.S. (2010). Community-based tourism ventures, benefits and challenges: Khama rhino sanctuary trust, central district, Botswana, Tourism Management, 31(1): 136-146. doi: 10.1016/j. tourman.2009.01.005.

52. Scheyvens, R. (2002). Tourism for development: empowering communities. Harlow: Pearson Education Limited.

53. Smith, V. (2000). Hosts and guests: The anthropology of tourism. Philadelphia University Press.

54. Southern Africa Tourism Service Association and European Union. The African Ivory Route. Online available https://www.africanivoryroute.co.za/ (March 19 2020)

55. Tasci et al. (2013). Community based tourism finding the equilibrium in COMCEC context: Setting the Pathway for the Future. Ankara: COMCEC Coordination Office

56. Terencia, N. M. (2018), Community based tourism and development in third world countries: the case of the Bamileke region of Cameroon. World academy of science, engineering and technology. International Journal of Social and Tourism Sciences, 12(1): 26-30

57. Tosun, C. (2000). Limits to community participation in the tourism development process in developing countries. Tourism Management 21, 613-633.

58. Tosun, C. (2006). Expected nature of community participation in tourism development. Tourism Management 27, 493-504

59. Um, S., Chon, K., \& Ro, Y-H. (2006). Antecedents of revisit intention. Annals of Tourism Research, 33, 11411158.

60. UNEP \& UNWTO (2005). Making Tourism More Sustainable - A Guide for Policy Makers. Online available http://wedocs.unep.org/bitstream/handle/20.500.11822/8741/-

Making\%20Tourism\%20More\%20Sustainable_\%20A\%20Guide\%20for\%20Policy\%20Makers2005445.pdf?sequence $=3 \&$ isAllowed $=y$ (February 11 2020)

61. UNWTO. Product Development. Online available https://www.unwto.org/tourism-development-products, (February 09 2020)

62. Van Raaij, W. F. (1986). Consumer research on tourism: Mental and behavioral constructs. Annals of Tourism Research, 13, 1-9.

63. Vegesayi, S., Mavondo, F. \& Reisinger, Y. (2009). Tourism Destination Attractiveness: Attractions, Facilities 
and People as predictators, Tourism Analysis, Vol. 14, pp. 621-636,

64. Vigolo, V. (2015). Investigating the Attractiveness of an Emerging Long-Haul Destination: Implications for Loyalty, International Journal of Tourism Research 17(6), 564-576, DOI: 10.1002/jtr.2024

65. Vu, T. H. C., (2014). Researh on Huong Pagoda Festival in Chuong Duc district, Ha noi city. Master thesis, Hanoi National University.

66. WTO (2002). Tourism and Poverty Alleviation. Online available https://www.eunwto.org/doi/pdf/10.18111/9789284405497, (January 30 2020)

67. $\mathrm{Wu}, \mathrm{L}$. (2012). A tourist behavior model system with multi-faceted dependencies and interactions. Doctor thesis, The Graduate School for International Development and Cooperation of Hiroshima University

About Vo Thi Quynh Nga

The author was born in Hanoi-Vietnam, in 1972. She has been a lecturer in the University of Economics, the University of Danang, Vietnam, since 1994 and is currently Dean of Tourism Faculty. She has got her DESS from Nantes University (France) in 1996 and her MBA form the University of Danang (Vietnam) in 2001. She earned her PhD degree in Industry Economics from the University of Danang in 2014. Her academic activities are concentrated in service marketing, competiveness and community-based tourism. She has had a number of articles published in several journals internationally and within Vietnam. 